\title{
IMAGE-SCHEMATIC STRUCTURING OF REALITY IN POLITICAL SPEECHES ON THE COVID-19 OUTBREAK
}

\author{
Ljerka Jeftić \\ Production and Management Faculty Trebinje, \\ University of East Sarajevo, \\ Bosnia and Herzegovina
}

\begin{abstract}
:
The paper is concerned with analysis of Donald Trump and Angela Merkel's speeches to their respective nations on the occasion of the COVID-19 outbreak. Within the integrated cognitivecritical approach to discourse analysis framework the paper focuses on the interplay between the cognitive mechanisms and discursive structures that make up meanings in a genre of political discourse. Assuming that specific actions and measures are to be communicated so as to deal with the threat presented by the coronavirus, analysis of the cognitive dimension of language use focuses on the underlying force (linguistically articulated by way of modal verbs) and containment image schemas considered as indicative of the ways the speakers conceive of the power vested in them. The political dimension analysis focuses on pronominal forms as discourse structures establishing relationships with addressees. The results point to D. Trump's self-representation of the protector of nation unlike A. Merkel's encouragement of solidarity empowered by knowledge-based joint actions and behaviour.
\end{abstract}

Keywords: discourse; cognition; embodiment of mind, image schema; modal verbs

\section{Introduction}

The global health emergency caused by the COVID-19 outbreak, at the beginning of 2020, called for urgent response and action on the side of all relevant factors worldwide. The global loss of life, the disruption of both world and national economies, the substantial lack of knowledge about the new form of coronavirus, all have brought about upheaval in every walk of life of almost unprecedented proportions experienced by the world's population over the last several decades. The World Health Organization (WHO) called for joint approach and coordination in suppressing the spread of the virus. Notwithstanding the WHO and other leading public health authorities' efforts to provide guidance and recommendation in managing the health crisis, the very newness of the virus, the number of lethal outcomes publicized daily and the uncertainties around the course of the COVID-19 infection, accompanied by the most decisive instruction to reduce mobility, exercise social distance and stay at home instilled fear in people. The

i Correspondence: email ljerka.jeftic@fpm.ues.rs.ba, ljerkajeftic 22@hotmail.com 
recommended social distancing was swiftly transposed to various forms of isolation, i.e. lockdowns, quarantines imposed by a number of governments thus generating the need for their political leaders to inform and explain to their respective constituencies/nations the specific measures being undertaken in the changed reality in which, among other things, the laws of the market economy, which used to be taken for granted, were to be replaced by the authority of the state, collective actions, solidarity and concern for the other.

Within the integrated cognitive-critical approach to discourse analysis framework, the paper is concerned with analysis of the use of language by USA President Donald Trump (https://www.nytimes.com/2020/03/11/us/politics/trump-coronavirus-speech.html) and German Chancellor Angela Merkel (English version at: https://www.general-anzeiger-bonn.de/gaenglish/news/angela-merkel-s-speech-about-the-corona-virus-in-full aid-49639811) in their speeches to their respective nations on the occasion of the COVID-19 outbreak. The approach brings together the cognitive dimension of language use with the social (political).

Analysis of the cognitive dimension of language use draws on the cognitive linguists' findings, e.g. Lakoff and Johnson's (1999), pertaining to the systematic grounding of language in human cognition, and the grounding of cognition in human embodiment. The very embodiment of our mind gives rise to our most pervasive experience of boundedness, of containment, while our existence as living organisms bound to interact with each other and the environment in order to survive implies our experience of force. Johnson (1987: xix) finds that such experience "directly influences [...] the ways in which the meanings can be developed and articulated, the ways we are able to comprehend and reason about our experience, and the actions we take". The influence of the containment experience is evident in, for instance, the common conceptualization of a country as a container (consisting of an interior and an exterior defined by a boundary) that Hart (2005: 190) finds to be the case in political discourse on immigration, whereby immigrants are represented and conceptualized as a threat. The paper postulates conceptualization and representation of the coronavirus as a threat in the speeches subjected to the analysis. How the threat is conceptualized and represented is to be revealed by focusing on the interplay between the cognitive mechanisms and discursive structures that make up meanings in the two speeches. Under the assumption that specific measures (actions) are to be communicated in the speeches so as to deal with the threat presented by the coronavirus, particular focus is placed on the underlying, nonpropositional image-schematic structuring of experience of force articulated linguistically by way of modal verbs in conveying the (COVID-19) pandemics related obligation, permission, request, or possibility of actions and behaviour.

With regards to the political (social) dimension of language use, the paper adopts Chilton and Schaffner's (1997: 216) view that by making a speech the speaker engages in a genre "which constitutes very particular relationships that are not only linguistic, but also social and political". In Van Dijk's (1997: 14) terms, what counts as political is, inter alia, determined by the participants, actions, and the context. The paper assumes that Donald Trump and Angela Merkel are political actors, communicating to their respective nations meanings pertaining to the social issue of health care in the context of a health emergency. Hence the inclusion into the analysis of first person singular and plural personal pronouns, which Van Dijk (1997: 25) recognizes as one of the preferred discourse structures "that are functional in the adequate accomplishment of political actions". 
The paper postulates that in the COVID-19 reality imbued with real, existing threat to people's lives, as opposed to the almost pervasive contemporary discursive construction of threat in politics (Wodak 2015; Altheide 2009), these two political leaders have to negotiate linguistic representation of the threat and thereof entailing imposition of serious restrictions without jeopardizing their own position of authority/power.

\section{Literature Review}

\subsection{Political Discourse}

Just what political is in language use or discourse is not always clearly delineated and set apart from other fields of discourse analysis. Owing to the inter/cross-disciplinary nature of discourse analysis, in particular the advancement of critical approach to discourse analysis (Fairclough 1995; Fowler 1996; Chilton 2004; van Dijk 1989; Wodak 2001), one is safe to approach the vast domain of politics from the linguistic perspective. Labeling it as a "critical enterprise", Van Dijk (1997: 11) claims that "critical-political discourse analysis deals especially with the reproduction of political power, power abuse or domination through political discourse". Along similar lines, Chilton (2004: 4) advocates the "need to explain how use of language can produce the effects of authority, legitimacy, consensus [...] that are recognized as being intrinsic to politics". The said effects presuppose interaction whereby representations, i.e., conceptualizations of the world and meanings are communicated by way of language use/discourse.

The characterization of any text and talk as political is provided by Chilton and Schaffner (1997: 212) who deem "as potentially political those actions (linguistic or other) which involve power, or its inverse, resistance". These authors (1997: 212-213) interpolate an intermediate level - strategic functions - between political processes and levels of discourse to enable the analysis of text and talk which is concerned with the details that make up what is understood as political. Relevant for the paper are the mutually closely linked strategic functions of coercion and legitimization, the former being directly linked with the exercise of power in that e.g., setting an agenda is an act of coercion, while the latter establishes the speaker's right to be obeyed which has to be linguistically communicated.

\subsection{Cognitive Science Framework}

Ever since the 1970s, when linguistic approaches to the meaning started intersecting with cognitive science, the meanings of words, of sentences and of discourses have been seen as being, as Chilton (2004: 48) argues, "in the mind, not objectively given" thus rendering e.g. political discourse a product of individual and collective mental processing (2004: 51). Proponents of integrating the findings of cognitive science within the critical approach to discourse analysis (Hart 2010, 2005; Chilton 2017; Van Dijk and Kintsch 1983) have brought together neurological findings, concerning structure and operation of our embodied brain, with the processes of thinking, understanding, interpreting and comprehending language (discourse) and the world. The main findings of cognitive science are nicely summarized by Lakoff and Johnson (1999: 3) "The mind is inherently embodied. Thought is mostly unconscious. Abstract concepts are largely metaphorical". The embodiment of mind (and reason) implies dependence of our concepts upon the body and our sensorimotor experience which give rise to conceptual (mental) structures 
which these authors (1999: 77) find to be "intrinsically meaningful by virtue of their connection to our bodies and our embodied experience". Such structures are commonly referred to as image schemas and defined by Johnson (1987: 29) as "recurrent pattern[s], shape[s], and regularity[ies]" in our experience of our bodily movements through space, our perceptional interaction, and our manipulation of objects. Johnson (1987: 41; 1987: 102) points to their gestalt structure in that they are our way of "being in the world", "our having the world". Lakoff (2004: xv) speaks of the unconsciousness of thought in terms of mental structures in the brain, called frames, which we are aware of by their consequences and which "shape the way we see the world". The metaphorical nature of abstract concepts Lakoff and Johnson (1980:3) relate to the metaphorical nature of our conceptual system thus rendering metaphor to be pervasive in thought, not just in language.

The paper is primarily concerned with the role of the FORCE image schema as it conceptualizes a prominent human experience which stems from our very nature of living organisms bound to interact with each other and the environment in order to survive - the experience of force, that is, forceful interaction. Johnson (1987: 43-44) finds that the general gestalt structure of force comprises features such as: interaction; directionality; a path of motion; source or origin of a force; degrees of intensity; structure or sequence of causality. In order to see how bodily experiences of force give rise to meaningful image schemas that can be transposed into other domains of meaning, such as reasoning or social interactions, Johnson (1987: 45-47) elaborates on seven particular FORCE schemas that constantly operate in our experience, four of which are of our concern in the paper: 1/ COMPULSION (the force comes from somewhere, has certain intensity, moves along a path, and has a direction); 2/ BLOCKAGE (when we interact forcefully with persons and objects in our environment, we often encounter obstacles that resist our force, or block it); 3/ COUNTERFORCE (head-on meetings of forces); 4/ ENABLEMENT (feeling of a sense of power to perform some action).

According to Sweetser's (1982) view of modality in terms of sociophysical concepts of forces and barriers (originating either from natural causes or from social restrictions or commitments), the root senses of modal verbs are related to our everyday experience of things, events, situations as being possible, necessary, obligatory, etc., and extended to the epistemic domain "precisely because we view our reasoning processes as being subject to compulsions, obligations, and other modalities" (1982: 484). From the point of view of meaningfulness of the FORCE image schemas, the inquiry into the root senses of modal verbs such as can, may, must, have to, and will means looking into the image schemas present in experiencing positive enablement to act due to removal of a barrier (can); permission to perform an act of choosing due to the absence of potential barrier (may); compulsion under forces beyond one's control (must); obligation to do something imposed by extrinsic authority or out of moral duty (have to); responsibility, volition and a completed path to an action or intention (will), the latter being one of the features of the force gestalt structure.

\section{Analysis}

Analysis of the speeches delivered by the US President Donald Trump and German Chancellor Angela Merkel to their respective nations on the occasion of the outbreak of COVID-19 pandemics is done separately comprising the analysis of cognitive dimension of language use, 
which focuses on image-schemas and therewith grounded conceptual metaphors and frames, and the political dimension concerned with the discursive aspects of the speeches.

\subsection{Donald Trump's Speech}

\subsubsection{Cognitive Dimension}

Donald Trump starts his speech with the COUNTERFORCE image schema underlying the headon meeting of the coronavirus outbreak that started in China with our nation's unprecedented response:

$$
\begin{aligned}
& \text { My fellow Americans, tonight I want to speak to you about our nation's } \\
& \text { unprecedented response to the coronavirus outbreak that started in China and is now } \\
& \text { spreading throughout the world. }
\end{aligned}
$$

This image schema underlies the overall frame of his speech - America's greatness triggered mainly by the superlatives:

(2) Our team is the best anywhere in the world.

(3) We have the greatest economy anywhere in the world, by far.

(4) We have the best economy, the most advanced health care, and the most talented doctors, scientists, researchers anywhere in the world.

The implicit confrontation with the other in the opening sentence reflects the conceptualization of the approach to the pandemics outbreak in terms of the WAR metaphor. Hence the incidence of the lexemes such as allies, protect, fight, confront, defeat:

We have been in frequent contact with our allies, and we are marshalling the full power of the federal government and the private sector to protect the American people.

We are at a critical time in the fight against the virus.

The opening sentence implicitly shifts the blame for the coronavirus outbreak on China. By labeling the virus foreign early in the speech, Trump assigns the enemy role to China as well:

The is the most aggressive and comprehensive effort to confront a foreign virus in modern history.

The WAR metaphor is grounded in the image schemas of CONTAINMENT and FORCE. As Chilton (217: 242) argues, the very meaning of words such as protect, safety, "require the activation of the container concept". We claim that the same goes for the word foreign which necessarily activates the container concept by implying the opposite - national, or even home country, which is conceptualized as a bounded space with emotionally positive value (e.g. the 
feeling of safety) under the condition that the threat is not coming from inside the container. To that end and in order to protect the safety of the American people, Trump speaks of restrictions of movement in the direction of the USA container with the underlying BLOCKAGE image schema:

(8) At the very start of the outbreak, we instituted sweeping travel restrictions on China...

(9) To keep new cases from entering our shores, we will be suspending all travel from Europe to the United States ... Anything coming from Europe is what we are discussing ...

The emotionally negative value assigned to a container is the case when one's path out from inside the container is blocked. This applies to the case of mandated quarantine which was put in place for the first time in over 50 years. The word refers to both a place and a period of isolation and in the particular case of the COVID-19 pandemic its meaning is staying at home for a certain period of time. This is where Trump speaks of the virus being inside the boundary of the USA again shifting the blame to the other, only, this time, to the Europeans:

As a result, a large number of new clusters in the United States were seeded by travelers from Europe.

The path in the direction out from the inside such an unfavorable container, that is the steps taken to deal with the pandemic, is conceptualized as (fast) movement:

$$
\text { We are moving very quickly. }
$$

Testing and testing capabilities are expanding rapidly, day by day.

I will never hesitate to take any necessary steps to protect the lives, health, and safety of American people.

\subsubsection{Modal Verbs}

The root sense of must is considered to denote a compelling force that moves a subject to an act and it matches the COMPULSION image schema. This kind of force has its source, moves along a path, and has a direction. The source of force in Trump's speech is his implied presidential authority to issue orders or commands given that, out of three occurrences of must in his speech, two refer to the exclusive we, as the following example shows:

$$
\text { Now we must take the same action with Europe. }
$$


The low frequency of occurrence of must is almost equal to the one of can (four occurrences), the root sense of which is found to be the absence of barriers and the capacity to act thus matching the ENABLEMENT image schema:

To ensure that working Americans impacted by the virus can stay home without fear of financial hardship ...

In contrast to these few uses of must and can, Donald Trump overwhelmingly resorts to categorical expressions of future certainty with the modal verb will. Sweetser (1982: 489) does not see any force or barrier in the purely future reading of will, yet finds it to indicate "a completed path to an action or intention" which we find to be in agreement with the path of motion feature within the gestalt structure of force. As Hart (2010:175) argues, "in contrast to the other modal verbs, will is reserved for expressions of predictability and has inherent in it a sense of certainty". The source of the communicated conviction and certainty (both seen as metaphorical force) in the speech is not in the propositions as such, but in the authority of the presidential function which is conceptualized here as a metaphorical force that coerces the addressee to accept the message as the truth:

I am confident that by counting and continuing to take these tough measures, we will significantly reduce the threat to our citizens and we will ultimately and expeditiously defeat this virus.

(18) The new rules will go into effect Friday midnight.

Out of the twenty-six occurrences of will in Trump's speech, four contain the will + progressive construction:

I will soon be taking emergency action, which is unprecedented, to provide financial relief.

Having in mind that this construction, as Quirk and Greenbaum (1987: 49) argue, conveys "greater tact and consideration than the simple auxiliary construction does", as well as the fact that in three cases it has $I$ as subject/agent, one is free to argue that it contributes to amplification of the forces of conviction and certainty as well as of representation of the speaker as a truthful narrator.

\subsubsection{Political Dimension}

The use of first person singular and plural pronouns in Donald Trump's speech accentuates the President and his administration's authority in the time of pandemics. At first sight, the incidence (sixteen) of the first person pronoun $I$ (and its form $m y$ ) when compared to that (forty-one) of the first person plural we (and its forms us and our) may imply alliance and solidarity as the political position of the speaker had it not been for the prevailing exclusive use of we referring to the president and the administrative bodies under his control. With regards to the use of first person singular pronominal, the addressees of Trump's speech are my fellow Americans: 
My fellow Americans, tonight I want to speak with you about our nation's unprecedented response to the coronavirus outbreak that started in China and is now spreading throughout the world.

The prefatory expression I want to speak with you serves the purpose of both preparing hearers to pay attention to what the President has to say and of defining "the speaker as authoritative source of information or knowledge", as Chilton and Schaffner (1997: 217) propose, that is, of legitimizing his social and political position.

This pronominal form is used as the subject/agent of specific verbs denoting actions already implemented, which aids to the speaker's representation as a man of action:

After consulting with our top government health officials, I have decided to take several strong but necessary actions to protect the health and well-being of all Americans.

In other instances, $I$ is the subject/agent of the sentences with modal will:

$$
\text { I will always put the well-being of America first. }
$$

By representing himself both as a man of action and a truthful narrator (certainty/truth expressed by the use of will) Trump takes on the role of the protector of the nation. The same role is assigned to his administration manifested in the use of exclusive we which, in the majority of occurrences (thirty out of total forty-one), refers to him and his administration:

We declared a public health emergency ....

At the same time, we are monitoring the situation in China and in South Korea.

The inclusive we, that is, the one that includes the addressees as well, has eleven occurrences which imply the rarely expressed calls for solidarity in Trump's speech:

$$
\text { We are all in this together. }
$$

To sum up, the analysis of cognitive and political dimensions of language use in Donald Trump's speech on the occasion of the COVID-19 outbreak reveals the conceptualization of a world dominated by the forces of conviction and certainty, the source of both being that of the presidential authority. The low incidence of FORCE image schemas of COMPULSION and ENABLEMENT (the higher presence of which one would expect given the extra-linguistic context of a threat and related measures/restrictions to be communicated) is indicative of the speaker's establishment of a relationship with addressees. Namely, despite the prefatory expression voiced at the onset of the speech (I want to speak with you), which implies a dialog, Donald Trump, actually, holds a coercive monologue by setting the agenda to talk about the greatness of America and his administration's actions. The confrontation conceptualized as WAR 
(both with the virus and China and others) legitimizes the self-assigned role of the nation's protector on the side of the speaker, and so do the occurrences of the pronominal forms.

\subsection{Angela Merkel's Speech}

\subsubsection{Cognitive Dimension}

Angel Merkel's opening sentence represents the coronavirus as an autonomous subject/agent active within the boundaries of our country:

(1) The coronavirus is currently changing life in our country dramatically.

Her prevalent conceptualization of the approach to the coronavirus is within the school/education frame activated by lexemes such as task, test, learn:

(2) Our ideas of normality, of public life, of social interaction - all of these are being put to the test as never before.

...this is a dynamic situation and we will remain capable of learning from it.

The fact that the corona virus is changing "life in our country" indicates the therewith underlying CONTAINMENT image schema applying to the epidemics as well:

(4) I would like to explain to you where we currently stand in the epidemic, ...

Being already in the country, that is, not having started or come from somewhere else, the spread of the virus at certain speed within the bounded space (Germany) is conceptualized via the JOURNEY metaphor:

$$
\text { ... slow down the virus on its way through Germany ... }
$$

There are only two instances of the WAR metaphor in Merkel's speech activated by the words forefront and combating, the latter being mitigated by the lexical choice effective means instead of e.g. weapons:

...the most effective means of combating the virus spreading too quickly - and that is ourselves.

The measures Angela Merkel proposes to confront the coronavirus force reveal the underlying image schema of BLOCKAGE, that is, blocking of the public life whereby public life is conceptualized as an open container (a building) that needs to be closed:

(7) I know how hard the closures, which have been agreed upon by the federal and state governments, interfere with our lives ... 


\subsubsection{Modal Verbs}

It is the extensive use of modal can that mainly characterizes Angela Merkel's speech. There are nineteen instances of the use with the underlying image schema of ENABLEMENT:

... how vulnerable we are, how dependent we all are on the considerate beahaviour of others, but also - how we can protect and strengthen each other by acting together.

The example above points to the overall frame of Merkel's speech - the one of caring/solidarity which is activated by numerous instances of joint solidarity, each of us, every life and person counts, close to each other:

(9) But I also want to explain why it needs you and what each and every one of you can contribute.

The compelling force of must (five incidences) is mitigated by either being juxtaposed with the ENABLEMENT force, or lexically, e.g. with remedy. Furthermore, the subject the compelling force is directed to is the inclusive we, and the compelled obligation is the one of common benefit:

We must limit the risk of one infecting the other as much as we can.

Likewise, the origin of the imposition of duty or obligation expressed by the use of have to (three instances) is within the domain of morality:

If you avoid necessary meetings, you will help those who have to deal with more cases every day in the hospitals.

The use of will (nineteen instances) in Merkel's speech is that of expressing simple futurity, conditionality, volition and responsibility:

But how high will the number of victims be?

... and if the shelves are emptied for a day, they will be refilled.

As a government, we will always re-examine what can be corrected...

This is a dynamic situation, and we will remain capable of learning from it ...

\subsubsection{Political Dimension}

The addressees of Angela Merkel's speech are fellow citizens, that is, all the citizens of the country for whom the official communications are being translated into many languages. The way Angela Merkel interacts, communicates, and establishes the relationship with the recipients of her speech is to appeal for solidarity and joint efforts. Besides explicit lexical choices in the speech, 
this function is enabled by the use of first person singular pronoun $I$, and its forms me and my (twenty-four occurrences) predominantly used in prefatory expressions. By preparing the hearers to focus on what is to be said, some of these convey the force of appeal:

I appeal to you: Stick to the rules that now apply for the near future.

Several prefatory expressions function to legitimize the role of speaker as an authoritative source of information and knowledge:

(2) On the epidemic - and everything I am telling you about it comes from the Federal Government's ongoing consultations with the experts of the Robert Koch Institute and other scientists and virologists ...

There are three occurrences of the use of the first person singular pronominal form by which the speaker directly addresses particular members of her audience to acknowledge and explicitly express appreciation for their roles and actions:

And let me also express my thanks here to people who are too rarely thanked.

The dominant frame of solidarity conceptualizing Angela Merkel's speech is evident in the use of the first person singular pronominal forms to communicate shared feelings and knowledge:

$$
\text { I know how hard it is to do what's being asked of us. }
$$

The solidarity frame is activated by the pronominal forms for first person plural, as well. Out of sixty occurrences of we and its forms, the reference of forty-seven is that of inclusion:

This is what an epidemic shows us: How vulnerable we all are, how dependent we are on the considerate behaviour of others, but also - how we can protect and strengthen each other by acting together.

The instances where this pronominal form refers to the speaker and the relevant administration/institutions while excluding the citizens are made the subjects of verbs from the semantic field associated with action for the common good:

(6) We can and will do everything we can to help our employers and employees through this difficult test.

$$
\text { But we also make political decisions transparent and explain them. }
$$

To conclude, the cognitive dimension of the language use in Angela Merkel's speech enables conceptualization of the COVID-19 reality as one of enablement, even empowerment of 
the members of the society to act out of moral duty and concern for the other by adhering to the advice and instructions coming from the relevant, expert entities. The ethical origin of force to be deployed in the pandemics is in line with the conceptualization of the threat (the coronavirus) not as an enemy penetrating the boundaries of the country container, but as an autonomous agent currently on the move within the country, exerting detrimental force which can be countered by knowledgeable behaviour (the school/education frame). The political dimension of language use reveals the speaker establishing the social and political relationship of unity and solidarity with the speaker taking on the responsibility stemming from the position she occupies.

\section{Discussion and Conclusion}

The aim of this paper was to show that cognitive science findings can contribute to research in political studies by bringing into conscious consideration the conceptual world a speaker, in the role of a social/political actor, constructs through discursive/linguistic choices. The specific objective of the study was to reveal the force image-schemas underlying the speakers' linguistic choices in terms of particular modal verbs and, by way of integrating these findings with some of the preferred structures of political discourse (notably, first person singular and plural pronominal forms), to discover the nature of relationships the speakers establish with their addresses in the state of health emergency caused by the COVID-19 pandemics outbreak. The focus on the force image-schemas was triggered by the expectation that these would be indicative of the particular ways the speakers conceive of the world and the power vested in them by the very social and political positions they occupy while communicating pandemics related measures and other pertinent information.

As Table 1 shows, simple frequency of occurrence of modal verbs in the speeches concerned with the present, serious health emergency is telling in that it points to Donald Trump's conceptualization of the world as the one yet to come into being manifested in the predominance of the modal will, which was found to be the linguistic expression of the underlying force image schema of conviction and certainty, over the hardly extant forces of enablement and compulsion, even moral duty:

Table 1: Frequency of occurrence of modal verbs

\begin{tabular}{|l|c|c|c|c|c|c|}
\hline Speaker & can & must & have to & may & should & will \\
\hline D. Trump & 4 & 3 & - & - & 1 & 26 \\
\hline A. Merkel & 19 & 5 & 3 & 1 & 3 & 19 \\
\hline
\end{tabular}

This conclusion can be corroborated by the fact that, out of the twenty-six occurrences, fifteen have the exclusive we or some other representative body of the US administration as their subject/agent. This is in stark contrast with the evident strong presence of the force of enablement found in Merkel's speech which can be interpreted as the speaker's committed consideration of and engagement in the present reality. Hence the higher incidence of the inclusive over the exclusive we (Table 2). The explanation of equal frequency of occurrence of will and can in A. Merkel's speech must take into account the therewith included three occurrences of the first conditional and two questions concerning the outcome of the pandemics, which reduces the 
frequency of will down to fourteen. Finally, the simple frequency of occurrence of other modal verbs in the analyzed speeches is indicative of the absence of the forces of moral duty and strong advice in Donald Trump's speech as oppose to Angela Merkel's, albeit infrequent, resorting to these, as well as other forms of modality.

The presence of the identified force image schemas, when compounded by the insight into the frequency of occurrence of the first person singular and plural pronouns (Table 2), provide for the interpretation of the established relationship with their respective audiences by the speakers.

Table 2: Frequency of occurrence of first person singular and plural pronouns

\begin{tabular}{|l|c|c|c|c|}
\hline Speaker & $\begin{array}{c}\text { I } \\
\text { (me, } \mathbf{m y})\end{array}$ & $\begin{array}{c}\text { we (our, us) } \\
\text { total }\end{array}$ & $\begin{array}{c}\text { we } \\
\text { inclusive }\end{array}$ & $\begin{array}{c}\text { we } \\
\text { exclusive }\end{array}$ \\
\hline D. Trump & 16 & 41 & 11 & 30 \\
\hline A. Merkel & 24 & 60 & 47 & 13 \\
\hline
\end{tabular}

The higher frequency of occurrence of $I$ (and me, my) in Angela Merkel's speech is accounted for its use in prefatory expressions, in direct addressing of particular members of society, as well as for communication of shared feelings and knowledge. On the other hand, Donald Trump's use of the first person singular pronoun is either predicated by the action verbs or by modal/auxiliary will thus representing the speaker as a man of action and a truthful narrator. Merkel's use of the first person singular pronoun to appeal for and encourage solidarity is in line with the use of predominantly inclusive we. Likewise, Donald Trump's self-representation as a man of action is matched by his use of mainly exclusive we which refers to the US administration/ institutions over which he has power and control.

The containment image schemas identified in both speeches give rise to two different conceptualizations of the coronavirus. While Donald Trump conceptualizes it as a threat/ enemy penetrating the borders of the country (as a container) from outside, Angela Merkel's conceptualization acknowledges its presence within the country's borders. Hence the presence of WAR metaphor in Trump's speech and the conceptual frame of solidarity empowered by knowledge in Merkel's speech.

\section{About the Author}

Ljerka Jeftić is an Associate Professor of English language at the Production and Management Faculty, University of East Sarajevo. She also teaches Discourse Analysis (PhD studies) at the Faculty of Philosophy, at the same university. Her research interest is in the field of critical discourse analysis and cognitive linguistics, as well as the relationship between language, discourse, media and politics. Her publication and published articles are concerned with the critical discourse analysis of the media reporting on terrorism; the globalization discourse in ICG reports on Bosnia and Herzegovina; the discourse of marketing; the EU enlargement discourse. 


\section{References}

Altheide D I, 2009. Terror Post 9/11 and the Media, New York: Peter Lang Publishing Inc.

Chilton P, Schaffner C, 1997. Discourse and Politics. Discourse Studies: A Multidisciplinary Introduction 2: 206-230.

Chilton P, 2004. Analyzing Political Discourse: Theory and Practice. London: Routledge.

Chilton P, 2017. Toward a Neuro-Cognitive Model of Socio-Political Discourse, and an Application to the Populist Discourse of Donald Trump. Éditions de la Maison des sciences de l'homme 2: 237-249.

Fairclough N, 1995. Critical Discourse Analysis: The Critical Study of Language. London: Longman Group Limited.

Fowler R, 1996. On Critical Linguistics. Texts and Practices: Readings in Critical Discourse Analysis: 3-15. London and New York: Routledge

Hart C, 2005. Analyzing Political Discourse: Toward a Cognitive Approach. Critical Discourse Studies 2 (2): 189-194.

Hart C, 2010. Critical Discourse Analysis and Cognitive Science: New Perspectives on Immigration Discourse. Palgrave Macmillan.

Johnson M, 1987. The Body in the Mind: The Bodily Basis of Meaning, Imagination, and Reason. Chicago and London: The University of Chicago Press.

Lakoff G, Johnson M, 1980. Metaphors We Live by. Chicago and London: The University of Chicago Press.

Lakoff G, Johnson M, 1999. Philosophy in the Flesh: The Embodied Mind and Its Challenge to Western Thought. New York: Basic Books.

Lakoff G, 2004. Don't Think of an Elephant! Chelsea: Green Publishing Company.

Quirk R, Greenbaum S, 1987 A University Grammar of English. Longman Group UK Limited.

Sweetser E, 1982. Root and Epistemic Modals: Causality in Two Worlds. Proceedings of the Eighth Annual Meeting of the Berkeley Linguistics Society: 484-507.

Van Dijk TA, Kintsch W, 1983. Strategies of Discourse Comprehension. New York: Academic Press.

Van Dijk TA, 1989. Structures of Discourse and Structures of Power. Communication Yearbook 12: 18-59. Newbury Park, CA: SAGE.

Van Dijk TA, 1997. What is Political Discourse Analysis. Political Linguistics: 11-52.

Wodak R, 2015. The Politics of Fear: What Right-Wing Populist Discourses Mean. Los Angeles/London/New Delhi/Singapore/Washington DC: SAGE.

Wodak R, 2001. What CDA Is About: A Summary of Its History, Important Concepts and Developments. Methods of Critical Discourse Analysis: 1-14. SAGE. 
Appendix 1: Donald Trump's Speech

Source: $\quad$ https://www.nytimes.com/2020/03/11/us/politics/trump-coronavirus-speech.html, 20.04.2020.

Speaking from the Oval Office, Mr. Trump announced a suspension of travel from Europe for 30 days, starting on Friday.

- March 11, 2020

$$
\begin{aligned}
& 0 \\
& 0 \\
& 0 \\
& 0
\end{aligned}
$$

My fellow Americans, tonight I want to speak with you about our nation's unprecedented response to the coronavirus outbreak that started in China and is now spreading throughout the world.

Today, the World Health Organization officially announced that this is a global pandemic. We have been in frequent contact with our allies, and we are marshaling the full power of the federal government and the private sector to protect the American people.

This is the most aggressive and comprehensive effort to confront a foreign virus in modern history. I am confident that by counting and continuing to take these tough measures, we will significantly reduce the threat to our citizens and we will ultimately and expeditiously defeat this virus.

From the beginning of time, nations and people have faced unforeseen challenges, including large-scale and very dangerous health threats. This is the way it always was and always will be. It only matters how you respond, and we are responding with great speed and professionalism.

Our team is the best anywhere in the world. At the very start of the outbreak, we instituted sweeping travel restrictions on China and put in place the first federally mandated quarantine in over 50 years. We declared a public health emergency and issued the highest level of travel warning on other countries as the virus spread its horrible infection.

And taking early intense action, we have seen dramatically fewer cases of the virus in the United States than are now present in Europe.

The European Union failed to take the same precautions and restrict travel from China and other hot spots. As a result, a large number of new clusters in the United States were seeded by travelers from Europe.

After consulting with our top government health professionals, I have decided to take several strong but necessary actions to protect the health and well being of all Americans.

To keep new cases from entering our shores, we will be suspending all travel from Europe to the United States for the next 30 days. The new rules will go into effect Friday at midnight. These restrictions will be adjusted subject to conditions on the ground.

There will be exemptions for Americans who have undergone appropriate screenings, and these prohibitions will not only apply to the tremendous amount of trade and cargo, but various 
other things as we get approval. Anything coming from Europe to the United States is what we are discussing. These restrictions will also not apply to the United Kingdom.

At the same time, we are monitoring the situation in China and in South Korea. And, as their situation improves, we will re-evaluate the restrictions and warnings that are currently in place for a possible early opening.

Earlier this week, I met with the leaders of health insurance industry who have agreed to waive all co-payments for coronavirus treatments, extend insurance coverage to these treatments, and to prevent surprise medical billing.

We are cutting massive amounts of red tape to make antiviral therapies available in record time. These treatments will significantly reduce the impact and reach of the virus.

Additionally, last week, I signed into law an $\$ 8.3$ billion funding bill to help C.D.C. and other government agencies fight the virus and support vaccines, treatments and distribution of medical supplies. Testing and testing capabilities are expanding rapidly, day by day. We are moving very quickly.

The vast majority of Americans: The risk is very, very low. Young and healthy people can expect to recover fully and quickly if they should get the virus. The highest risk is for elderly population with underlying health conditions. The elderly population must be very, very careful. In particular, we are strongly advising that nursing homes for the elderly suspend all medically unnecessary visits. In general, older Americans should also avoid nonessential travel in crowded areas.

My administration is coordinating directly with communities with the largest outbreaks, and we have issued guidance on school closures, social distancing and reducing large gatherings. Smart action today will prevent the spread of the virus tomorrow.

Every community faces different risks and it is critical for you to follow the guidelines of your local officials who are working closely with our federal health experts - and they are the best.

For all Americans, it is essential that everyone take extra precautions and practice good hygiene. Each of us has a role to play in defeating this virus. Wash your hands, clean often-used surfaces, cover your face and mouth if you sneeze or cough, and most of all, if you are sick or not feeling well, stay home.

To ensure that working Americans impacted by the virus can stay home without fear of financial hardship, I will soon be taking emergency action, which is unprecedented, to provide financial relief. This will be targeted for workers who are ill, quarantined, or caring for others due to coronavirus.

I will be asking Congress to take legislative action to extend this relief.

Because of the economic policies that we have put into place over the last three years, we have the greatest economy anywhere in the world, by far.

Our banks and financial institutions are fully capitalized and incredibly strong. Our unemployment is at a historic low. This vast economic prosperity gives us flexibility, reserves, and resources to handle any threat that comes our way.

This is not a financial crisis, this is just a temporary moment of time that we will overcome together as a nation and as a world. 
However, to provide extra support for American workers, families, and businesses, tonight I am announcing the following additional actions: I am instructing the Small Business Administration to exercise available authority to provide capital and liquidity to firms affected by the coronavirus.

Effective immediately, the S.B.A. will begin providing economic loans in affected states and territories. These low-interest loans will help small businesses overcome temporary economic disruptions caused by the virus. To this end, I am asking Congress to increase funding for this program by an additional $\$ 50$ billion.

Using emergency authority, I will be instructing the Treasury Department to defer tax payments, without interest or penalties, for certain individuals and businesses negatively impacted. This action will provide more than $\$ 200$ billion of additional liquidity to the economy. Finally, I am calling on Congress to provide Americans with immediate payroll tax relief. Hopefully they will consider this very strongly.

We are at a critical time in the fight against the virus. We made a lifesaving move with early action on China. Now we must take the same action with Europe. We will not delay. I will never hesitate to take any necessary steps to protect the lives, health, and safety of the American people. I will always put the well being of America first.

If we are vigilant - and we can reduce the chance of infection, which we will - we will significantly impede the transmission of the virus. The virus will not have a chance against us.

No nation is more prepared or more resilient than the United States. We have the best economy, the most advanced health care, and the most talented doctors, scientists and researchers anywhere in the world.

We are all in this together. We must put politics aside, stop the partisanship and unify together as one nation and one family.

As history has proven time and time again, Americans always rise to the challenge and overcome adversity.

Our future remains brighter than anyone can imagine. Acting with compassion and love, we will heal the sick, care for those in need, help our fellow citizens and emerge from this challenge stronger and more unified than ever before.

God bless you, and God bless America. Thank you. 
Appendix 2: Angela Merkel's speech

Source: https://www.general-anzeiger-bonn.de/ga-english/news/angela-merkel-s-speech-aboutthe-corona-virus-in-full aid-49639811 27.4.2020.

Appeal to the people living in Germany

Angela Merkel's speech about the Corona virus in full

19.3.2020.

\section{Dear fellow citizens,}

The coronavirus is currently changing life in our country dramatically. Our ideas of normality, of public life, of social interaction - all of these are being put to the test as never before.

Millions of you can't go to work, your children can't go to school or go to daycare, theatres and cinemas and shops are closed and, what is perhaps the hardest thing, we all miss the human encounters that are otherwise taken for granted. Of course, in such a situation, each of us is full of questions and worries about how to go on.

I turn to you today in this unusual way because I want to tell you what guides me as Chancellor and all my colleagues in the Federal Government in this situation. This is part and parcel of an open democracy: But we also make political decisions transparent and explain them. We justify and communicate our actions as well as possible so that they are comprehensible.

I firmly believe that we will succeed in this task if all citizens see it as their task.

So let me say that this is serious. Take it seriously too.

Since the German reunification, no, since the Second World War, there has not been a challenge to our country that depends so much on our joint solidarity.

I would like to explain to you where we currently stand in the epidemic, what the federal government and the levels of government are doing to protect everyone in our community and limit the economic, social, to protect everyone in our community and limit the economic, social, cultural damage. But I also want to explain why it needs you and what each and every one of you can contribute.

On the epidemic - and everything I am telling you about it comes from the Federal Government's ongoing consultations with the experts of the Robert Koch Institute and other scientists and virologists: research is being carried out under high pressure all over the world, but there is still neither a therapy against the coronavirus nor a vaccine.

As long as this is the case, there is only one thing we can do, and that is to slow down the spread of the virus, stretch it over the months and thus gain time. Time for research to develop a drug and a vaccine. But above all time so that those who fall ill can receive the best possible care.

Germany has an excellent healthcare system, perhaps one of the best in the world. That can give us confidence. But our hospitals would also be completely overwhelmed if too many 
patients who suffer a severe course of Corona infection were admitted in the shortest possible time.

These are not just abstract numbers in a statistic, but a father or grandfather, a mother or grandmother, a partner, they are people. And we are a community in which every life and every person counts.

I would like to take this opportunity to address first and foremost all those who work as doctors, in the nursing service or in any other function in our hospitals and in the health care system in general. They are at the forefront of this struggle. They are the first to see the sick and to see how severe some courses of infection are. And every day you go back to your work and you are there for the people. What you do is tremendous, and I thank you for it with all my heart. So: the aim is to slow down the virus on its way through Germany. And in doing so, we have to rely on one thing, which is existential: to shut down public life as far as possible. Of course, with reason and a sense of proportion, because the state will continue to function, the supply will continue to be secured and we want to preserve as much economic activity as possible.

But everything that could endanger people, everything that could harm not only the individual, but also the community, we must reduce that now. We must limit the risk of one infecting the other as much as we can.

I know how dramatic the restrictions are already now: no more events, no more fairs, no more concerts and for the time being no more school, no university, no kindergarten, no playing in a playground. I know how hard the closures, which have been agreed upon by the federal and state governments, interfere with our lives and also with our democratic self-image. They are restrictions such as have never been seen before in the Federal Republic.

Let me assure you: For someone like me, for whom freedom of travel and movement was a hardwon right, such restrictions can only be justified as an absolute necessity. In a democracy, they should never be decided lightly and only temporarily - but at the moment they are indispensable to save lives.

That is why the tightened border controls and entry restrictions to some of our most important neighbouring countries have been in force since the beginning of the week.

It is already very difficult for the economy, for large companies as well as small businesses, for shops, restaurants, freelancers. The coming weeks will be even harder. I can assure you: The German government is doing everything it can to cushion the economic impact - and above all to preserve jobs.

We can and will do everything we can to help our employers and employees through this difficult test.

And everyone can rest assured that the food supply is secure at all times, and if shelves are emptied for a day, they will be refilled. I would like to say to everyone who goes around to the supermarkets: stockpiling makes sense, it always has, by the way. But with moderation. Hoarding, as if nothing will ever be available again, is pointless and ultimately completely lacking in solidarity.

And let me also express my thanks here to the people who are too rarely thanked. These days, anyone who sits at a supermarket checkout or fills shelves is doing one of the hardest jobs there is at the moment. Thank you for being there for your fellow citizens and literally keeping the place running. 
Now to what I feel is the most urgent need today: All government measures would achieve nothing if we did not use the most effective means of combating the virus spreading too quickly - and that is ourselves. Just as any one of us, indiscriminately, can be affected by the virus, so now everyone must help. First and foremost, by taking seriously what we are talking about today. Don't panic, but don't think for a moment that he or she doesn't really matter. No one is expendable. Everyone counts, it takes all our efforts.

This is what an epidemic shows us: How vulnerable we all are, how dependent we are on the considerate behaviour of others, but also - how we can protect and strengthen each other by acting together.

It depends on everyone. We are not condemned to passively accept the spread of the virus. We have a remedy for this: we must keep our distance out of consideration for each other. The advice of the virologists is clear: no more handshakes, wash your hands thoroughly and often, at least one and a half metres away from the next person and, preferably, hardly any contact with the very old, because they are particularly at risk.

I know how hard it is to do what's being asked of us. We want to be close to each other, especially in times of need. We know affection as physical closeness or touch. But right now, unfortunately, the opposite is true. And that's what we all need to understand: Right now, distance is the only way to express caring.

The well-intentioned visit, the journey that did not have to be, all this can be contagious and should really not take place now. There is a reason why the experts say: grandparents and grandchildren should not get together now.

If you avoid unnecessary meetings, you will help all those who have to deal with more cases every day in the hospitals. This is how we save lives. This will be difficult for many, and that's what it will come down to: not leaving anyone alone to take care of those who need encouragement and confidence. As families and as a society, we will find other ways to help each other.

There are already many creative forms that defy the virus and its social consequences. Already there are grandchildren who are recording a podcast for their grandparents so they won't be lonely.

We all have to find ways to show affection and friendship: Skype, phone calls, emails and maybe write letters again. The mail is getting delivered. We now hear about wonderful examples of neighbourhood help for the elderly who cannot go shopping themselves. I am sure there is much more to come and we will show as a community that we do not leave each other alone.

I appeal to you: Stick to the rules that now apply for the near future. As a government, we will always re-examine what can be corrected, but also what may still be necessary.

This is a dynamic situation, and we will remain capable of learning from it, so that we can always rethink and react with other instruments. We will then explain that too. That is why I ask you not to believe rumours, but only the official communications, which we always have translated into many languages.

We are a democracy. We do not live by constraint, but by shared knowledge and participation. This is an historic task and it can only be accomplished together. 
I am absolutely certain that we will overcome this crisis. But how high will the number of victims be? How many loved ones will we lose? It is largely in our own hands. We can now, resolutely, all react together. We can accept the current limitations and stand by each other.

This situation is serious and it is open.

This means that it will depend not only, but also on how disciplined everyone follows and implements the rules.

We must show, even if we have never experienced anything like this before, that we act cordially and reasonably and thus save lives. Without exception, it depends on each individual and therefore on all of us.

Take good care of yourself and your loved ones.

I thank you.

(Translation: Mareike Graepel) 